\begin{tabular}{|l|l|l||}
\hline \multicolumn{2}{|c|}{ PublisherInfo } \\
\hline \hline PublisherName & $:$ & BioMed Central \\
\hline \hline PublisherLocation & $:$ & London \\
\hline \hline PublisherImprintName & $:$ & BioMed Central \\
\hline \hline
\end{tabular}

\title{
Variation on the fourth
}

\begin{tabular}{|l|l|l||}
\hline \multicolumn{2}{|c|}{ ArticleInfo } \\
\hline \hline ArticleID & $:$ & 4371 \\
\hline \hline ArticleDOI & $:$ & $10.1186 /$ gb-spotlight-20020108-01 \\
\hline \hline ArticleCitationID & $:$ & spotlight-20020108-01 \\
\hline \hline ArticleSequenceNumber & $:$ & 37 \\
\hline \hline ArticleCategory & $:$ & Research news \\
\hline \hline ArticleFirstPage & $:$ & 1 \\
\hline \hline ArticleLastPage & $:$ & 2 \\
\hline \hline & & RegistrationDate : 2002-01-08 \\
ArticleHistory & $:$ & OnlineDate $\quad$ 2002-01-08 \\
\hline \hline ArticleCopyright & $:$ & BioMed Central Ltd2002 \\
\hline \hline ArticleGrants & $:$ & \\
\hline \hline ArticleContext & $:$ & 130593311 \\
\hline \hline
\end{tabular}




\section{Jonathan B Weitzman}

Email: jonathanweitzman@hotmail.com

The fourth chromosome of Drosophila melanogaster was believed to be free from variation and meiotic recombination, leading to several theories about its selection and evolution. In the January 4 Science, Wen Wang and researchers at the University of Chicago challenge these theories with their discovery of regions of variation along the chromosome (Science 2002, 295:134-137). They analysed nucleotide sequence around the toy gene locus from many fly collections worldwide. The observation that there was significant haplotype sequence variation prompted them to investigate further. They sequenced additional gene regions along the fourth chromosome and found that some areas varied while other did not. They could divide the chromosome into three distinct domains, which may reflect different evolutionary histories. Wang et al. also found evidence for six recombination events on the fly chromosome. These observations will encourage a reassessment of the importance of genetic and evolutionary forces affecting the fourth chromosome.

\section{References}

1. Lack of polymorphism on the Drosophila fourth chromosome resulting from selection.

2. Science, [http://www.sciencemag.org]

3. The University of Chicago, [http://www.uchicago.edu] 